\title{
STUDIES ON NITROFURAN CONTAMINATION IN EXPORTABLE SHRIMP AND PRAWN PRODUCTS
}

\author{
A. K. M. Nowsad, M. R. Islam and M. A. R. Faruk \\ Department of Fisheries Technology, Bangladesh Agricultural University \\ Mymensingh-2202, Bangladesh
}

\begin{abstract}
For the last few years, several consignments of frozen prawn and shrimp from Bangladesh have been rejected by the EU and USA due to presence of nitrofuran drugs. We have investigated the source of nitrofuran drugs in shrimp and prawn through participatory stakeholder based approach. Survey in greater Mymensingh region revealed that most of the hatchery operators and prawn farmers did not know about the devastating effect of nitrofuran on prawn while survey in Cox's Bazar and Khulna revealed that most of the hatchery operators knew about the nitrofuran drugs but they kept mum on nitrofuran related issues. A series of antibiotics sold in local veterinary drug shops of Cox's Bazar and Khulna were found to be used in shrimp hatcheries. While conducting stakeholder based dialogue in Khulna and Cox's Bazar, hatchery operators were directly blamed by shrimp/prawn farmers, depot holders and processors for using nitrofuran drug. Many hatchery technicians mentioned that they used nitrofuran drugs in the hatcheries 5-6 years back, much before than it was declared banned on shrimp products, but at present they were not using it. While asking about the unlabelled drugs using in their hatcheries, they did not respond but mentioned the efficacy of nitrofuran in the survival of shrimp/prawn PL and promotion of their growth. From the participatory stakeholder based study it was understood that both the prawn/shrimp hatchery and poultry feed/fish feed used as shrimp/prawn feed in grow out ponds might be the possible sources of contamination of nitrofuran drugs in exportable shrimp/prawn products.
\end{abstract}

Key words : Nitrofuran, Shrimp/prawn products, Hatchery, Shrimp/prawn feed

\section{INTRODUCTION}

The frozen food industries have become the second largest export sector which registered a total export earning of $\$ 408.87$ million in the July-March period of the fiscal year 2007-08 compared to that of \$ 3.17 million in 1972-73. Nitrofuran contamination is appearing as a serious blow to the steady growth of this sector. Due to carcinogenic effect of nitrofuran, it has been declared completely unfit (zero tolerance limit) for human consumption (Finzi et al., 2005). Fast growing frozen shrimp/prawn export sector is now at serious stake due to such zero tolerance policy of the EU and hard lining of the FDA on presence of nitrofuran drugs (DoF, 2006). 
Nitrofurans are frequently employed in the poultry and fish production for their excellent antibacterial, pharmacokinetic and growth promoting properties (Hartig et al., 2005). Due to a multi-stakeholder involvement in the chain of production, transportation, marketing and processing of fish and shrimp in Bangladesh, it seems increasingly difficult to identify the sources of antibiotic contamination. Such contamination in fish foods may occur from the water supply, feed, hatchery produced seed, etc. and by the primary producers and other traders in the handling and distribution chain and finally by the processors and packers. If such unethical contamination continued, rapidly expanding fisheries sector will be doomed, millions of people will be unemployed and finally, the county's economy will be devastated. Considering such backdrop the study was conducted to investigate the source of nitrofuran drugs in shrimp and prawn through participatory stakeholder based approach. It is the first investigation of its kind in Bangladesh.

\section{MATERIALS AND METHODS}

\section{Study area}

To conduct the study three major locations were selected. These were- Mymensingh area for hatchery and husbandry of exportable prawn; Khulna, Satkhira and Bagerhat area for farming and processing of shrimp/prawn and Chittagong and Cox's Bazar zone for hatchery operation, aquaculture and processing of shrimp.

\section{Collection of secondary information}

All sorts of secondary information concerning use of nitrofuran in shrimp and prawn were collected from the print and electronic domains, books, journals, periodicals, reports, news papers, internet browsing, institutions/persons, GO/NGO bodies and from different stakeholders of this sector.

\section{Review of the information}

Collected information was reviewed very critically. Several expert consultations were made to obtain a detailed overview of both legal and technical aspects of antibiotic use in shrimp and prawn.

\section{Collection of primary information}

Two methods were employed: questionnaire survey and stakeholder-based dialogue. Questionnaire surveys were conducted through several semi structured questionnaire formats. The collected data were cross-checked, verified and field tested through rapid rural appraisals (RRAs), group discussions, brain storming and personal contacts.

Taking the nitrofuran issue as a serious concern, a series of dialogue in the form of workshop, RRA, focused group discussion (FGD) and brain storming were carried out with the stakeholders in Khulna, Chittagong, Cox's Bazar and Mymensingh. Firstly, several distinctive RRAs were conducted on the shrimp farmers, hatchery operators and 
traders in Khulna and Cox'a Bazar. Same was done with the prawn farmers and hatchery operators of five upazilas of Mymensingh - Fulpur, Gouripur, Sadar, Trishal and Valuka. Government machinery like district and upazila fisheries administration, upazila level fish farm managers and Deputy Directors of Fish Inspection \& Quality Control (FIQC) wing of the Department of Fisheries (DoF) in Chittagong and Khulna were involved in such dialogues to cross-cut the argument of different stakeholders in the value chain. Stakeholder-based workshops on nitrofuran use and its impact on shrimp industry was organized in Khulna and Cox's Bazar with different stakeholders of the value chain as participants. Main stakeholders were shrimp/prawn farmers, hatchery owners, hatchery operators/technicians, PL traders, shrimp/prawn transporters, depot holders, feed processors, processing factory owners, NGOs, research institutes, FIQC officials and academia personnel. Valuable information related to the contamination of shrimp/ prawn by nitrofuran derivatives have come out from the workshops. Different stakeholders were allowed to discuss on common specific items separately. The team leader of each stakeholder group presented respective group outputs. The participants were given full freedom to discuss the current situations of shrimp/prawn industry in general and nitrofuran contamination in particular. Presentations provoked the participants to uncork the mouth and actively take part in the discussion. Crossdiscussion, justifications of issues, cross-cutting answers, arguments and counterarguments, etc. laid a genuine platform for finding out the fact behind the use of nitrofuran in prawn and shrimp. These stakeholder-based workshops made strong basis for contributing to the policy deriving workshops organized by the Department of Fisheries and the Ministry of Fisheries and Livestock in Dhaka, where all policy making, regulatory and implementing agencies were participated.

\section{RESULTS AND DISCUSSION}

Three questionnaire surveys were conducted on shrimp/prawn farmers and hatchery operators of Mymensingh, Khulna and Cox's Bazar regions.

Survey in Mymensingh area revealed that most often the operators and farmers were reluctant to give authentic information. Most of them did not know the devastating effects of nitrofuran metabolites in prawn products. Almost all hatchery owners did not hear about nitrofuran before. However, they had heard about chloramplenicol. They never used nitrofuran and chloramphenicol in either prawn post larvae (PL) production in hatcheries or culture in grow-out ponds. Among the antibiotics, they used only renamycin and oxy-tetracycline (OTC) for treatment of prawn disease (Table 1). In the ponds, farmers used formalin, calcium hydroxide, zeolite, methyl blue and cee-vit (Vitamin C) for treatment of disease. Ex-ADB Hatchery Manager, now Senior Upazila Fisheries Officer of Gouripur, Mymensingh told that labeled nitrofuran drugs had been frequently used in shrimp hatcheries in Cox's Bazar 6-8 years back. After imposing ban on it, foreign technicians removed the nitrofurans and instead of these, they had started using huge unlabelled antibiotics in the hatcheries. Due to effective bactericidal and 
growth promoting characteristics, it was assumed that these unlabelled ones were no doubt but any banned drugs.

Table 1. Veterinary drugs used in Mymensingh area for freshwater prawn PL production

\begin{tabular}{|c|c|c|c|c|c|c|c|}
\hline \multirow{2}{*}{$\begin{array}{l}\text { Name of the } \\
\text { hatchery }\end{array}$} & \multicolumn{2}{|c|}{ Supplementary feed used } & \multirow{2}{*}{$\begin{array}{l}\text { Disease out } \\
\text { break }\end{array}$} & \multicolumn{2}{|c|}{ Antibiotic used } & \multicolumn{2}{|c|}{ Growth promoter } \\
\hline & Name & Rate & & Name & Dose & Name & Dose \\
\hline $\begin{array}{l}\text { Kashigonj } \\
\text { Golda } \\
\text { Hatchery } \\
\text { (Fulpur) }\end{array}$ & $\begin{array}{l}\text { Artemia and } \\
\text { custard (Egg, } \\
\text { Milk, Vit. B, C, } \\
\text { Mineral) }\end{array}$ & $\begin{array}{c}2 / 3 / 4 \\
\text { Times } \\
\text { depends on } \\
\text { condition }\end{array}$ & $\begin{array}{l}\text { White spot, } \\
\text { louse, } \\
\text { zoothamnia }\end{array}$ & $\begin{array}{l}\text { Formalin } \\
\text { OTC, B50 }\end{array}$ & $\begin{array}{l}1.25 \mathrm{~g} / \\
\text { Ton }\end{array}$ & Cyclopis & 14/Ton \\
\hline $\begin{array}{l}\text { Grehanggon } \\
\text { Hatchery } \\
\text { (Fulpur) }\end{array}$ & $\begin{array}{l}\text { Artemia and } \\
\text { custard (Egg, } \\
\text { Milk, Flaour) }\end{array}$ & $\begin{array}{c}2 / 3 / 4 \text { times } \\
\text { depends on } \\
\text { condition }\end{array}$ & White spot & Renamycin & $2 \mathrm{~g} /$ Ton & Cyclopis & 10/Ton \\
\hline $\begin{array}{l}\text { Grehanggon } \\
\text { Hatchery } \\
\text { (Fulpur) }\end{array}$ & $\begin{array}{l}\text { Artemia and } \\
\text { custard (Egg, } \\
\text { Milk, Flaour) }\end{array}$ & $\begin{array}{c}2 / 3 / 4 \text { times } \\
\text { depends on } \\
\text { condition }\end{array}$ & Not occurred & Not used & Not used & Not used & Not used \\
\hline $\begin{array}{l}\text { Zalak Fresh } \\
\text { water Golda } \\
\text { Hatchery } \\
\text { (Gouripur) }\end{array}$ & $\begin{array}{l}\text { Artemia and } \\
\text { custard (Egg, } \\
\text { Milk, vit. B, C } \\
\text { cod oil) }\end{array}$ & $\begin{array}{c}2 / 3 / 4 \text { times } \\
\text { depends on } \\
\text { condition }\end{array}$ & $\begin{array}{c}\text { Parasite, spot, } \\
\text { bacterial disease }\end{array}$ & OTC & $1.2 \mathrm{~g} /$ Ton & Cyclopis & $\begin{array}{l}\text { 10-12 } \\
\text { /Ton }\end{array}$ \\
\hline $\begin{array}{l}\text { Grehanggon } \\
\text { Hatchery } \\
\text { (Trishal) }\end{array}$ & $\begin{array}{l}\text { Artemia and } \\
\text { custard (Egg, } \\
\text { Milk, Flaour) }\end{array}$ & $\begin{array}{c}2 / 3 / 4 \text { times } \\
\text { depends on } \\
\text { condition }\end{array}$ & $\begin{array}{l}\text { Rapid death } \\
\text { with out } \\
\text { showing any } \\
\text { symptom }\end{array}$ & Renamycin & $1-2 \mathrm{~g} / \mathrm{Ton}$ & Not used & Not used \\
\hline $\begin{array}{l}\text { Agro-3 } \\
\text { (Trishal) }\end{array}$ & $\begin{array}{l}\text { Artemia and } \\
\text { custard (Egg, } \\
\text { Milk, Vit. B, C } \\
\text { Mineral, cod oil ) }\end{array}$ & $\begin{array}{c}2 / 3 / 4 \text { times } \\
\text { depends on } \\
\text { condition }\end{array}$ & Parasite, spot & OTC & $1.5 \mathrm{~g} /$ Ton & Not used & Not used \\
\hline $\begin{array}{l}\text { BFRI } \\
\text { Mymensingh }\end{array}$ & $\begin{array}{l}\text { Artemia and } \\
\text { custard (Egg, } \\
\text { Milk, Flaour) }\end{array}$ & $\begin{array}{c}2 / 3 / 4 \text { times } \\
\text { depends on } \\
\text { condition }\end{array}$ & $\begin{array}{l}\text { Bacterial disease } \\
\text { (Rapid death) }\end{array}$ & Renamycin & $\begin{array}{l}1 \text { pellet/ } \\
300 \text { litre }\end{array}$ & Not used & Not used \\
\hline
\end{tabular}

Questionnaire survey conducted in Cox's Bazar area could not bring adequate information to draw out any conclusive comments on PL production and culture of marine shrimp. It was understood that most of the hatchery operators knew about the nitrofuran drugs but they kept mum, while discussed, on nitrofuran related issues. Many antibiotics were mentioned to be used like OTC, chloramphenicol, attropin sulphate, finthyd, nolenon, carbafuran, etc. (Table 2). Many unlabelled antibiotics were found to be used in the hatcheries. Chloramphenicol, although well-known as a banned antibiotic for use in shrimp, was reported to be used in the hatcheries of Cox's Bazar. Most of the answers of the hatchery operators were negative. Sometimes they opened mouth for a particular drug as being used in the hatchery but soon they denied or reluctant to tell the exact dose using. Some of the growth promoter type drugs mentioned was epicin, probiotics, nitrofuran, etc. 
Questionnaire survey in Khulna area revealed that farms in southern Khulna region had been using Indian PL, as being sold in the black market. Local drug houses were found to sell chloramphenicol, OTC, attropin sulphate, finthyd, nolenon, carbafuran and many other unlabeled and undisclosed antibiotics (Table 2). Hatcheries were reported to use chloramphenicol (Bacteriocide-CL) and OTC (Bacteriocide-OTC) for treatment of disease. Hatchery technicians were reported to use many unknown antibiotics for better production and survival of PL. Like-wise Cox's Bazar, hatchery technicians of Khulna region also kept mum on nitrofuran drugs, some one disclosed the information on tremendous PL survival and growth promoting charisma of nitrofuran. Many hatchery technicians told that they used nitrofuran drugs in the hatcheries 5-6 years back, well before it was declared ban on shrimp products, but now they were not using it. While asking about any unlabelled drugs using in their hatcheries, they became furious and did not answer.

Table 2. Veterinary drugs used in Cox's Bazar and Khulna for PL production of marine shrimp

\begin{tabular}{|c|c|c|c|c|c|c|c|}
\hline \multirow[t]{2}{*}{ Location } & \multicolumn{2}{|c|}{ Supplementary feed used } & \multirow{2}{*}{$\begin{array}{c}\text { Disease out } \\
\text { break }\end{array}$} & \multicolumn{2}{|c|}{ Antibiotic using } & \multicolumn{2}{|c|}{ Growth promoter } \\
\hline & Name & Rate & & Name & Dose & Name & Dose \\
\hline $\begin{array}{l}\text { Cox's } \\
\text { Bazar } \\
\text { Sadar }\end{array}$ & $\begin{array}{l}\text { Starter feed, } \\
\text { plankton, } \\
\text { minerals, } \\
\text { etc }\end{array}$ & $\begin{array}{c}2 / 3 / 4 \text { times } \\
\text { depends on } \\
\text { condition }\end{array}$ & $\begin{array}{c}\text { Luminous } \\
\text { bacteria (LB) } \\
\text { white spot }\end{array}$ & $\begin{array}{c}\text { OTC, } \\
\text { chloramphenicol, } \\
\text { attropin sulphate, } \\
\text { finthyd, nolenon, } \\
\text { carbafuran, } \\
\text { nitrofuran }\end{array}$ & $\begin{array}{l}\text { Unknown } \\
\text { as reluctant } \\
\text { to disclose }\end{array}$ & $\begin{array}{l}\text { Epicin, } \\
\text { probiotics, } \\
\text { nitrofuran } \\
\text { drugs }\end{array}$ & $\begin{array}{c}\text { Not } \\
\text { known }\end{array}$ \\
\hline Ukhiya & $\begin{array}{l}\text { Starter feed, } \\
\text { plankton, } \\
\text { minerals, } \\
\text { etc }\end{array}$ & $\begin{array}{c}2 / 3 / 4 \text { times } \\
\text { depends on } \\
\text { condition }\end{array}$ & $\begin{array}{l}\text { LB, white } \\
\text { spot }\end{array}$ & $\begin{array}{c}\text { Renamycin, } \\
\text { OTC,chloramphenic } \\
\text { ol, finthyd, nolenon, } \\
\text { carbafuran, } \\
\text { nitrofuran } \\
\end{array}$ & same & $\begin{array}{c}\text { Unknown } \\
\text { nitrofuran } \\
\text { drugs }\end{array}$ & $\begin{array}{c}\text { Not } \\
\text { known }\end{array}$ \\
\hline Khulna & $\begin{array}{l}\text { Starter feed, } \\
\text { plankton, } \\
\text { minerals, } \\
\text { etc }\end{array}$ & $\begin{array}{c}2 / 3 / 4 \text { times } \\
\text { depends on } \\
\text { condition }\end{array}$ & $\begin{array}{l}\text { LB, white } \\
\text { spot }\end{array}$ & $\begin{array}{l}\text { OTC,chloramphenic } \\
\text { ol, attropin sulphate, } \\
\text { finthyd, nolenon, } \\
\text { carbafuran, } \\
\text { nitrofurazon }\end{array}$ & same & $\begin{array}{c}\text { Unknown } \\
\text { nitrofuran } \\
\text { drugs }\end{array}$ & $\begin{array}{c}\text { Not } \\
\text { known }\end{array}$ \\
\hline $\begin{array}{l}\text { Govt } \\
\text { hatcheries } \\
\text { (Cox's } \\
\text { Bazar, } \\
\text { Khulna) }\end{array}$ & $\begin{array}{l}\text { Starterfeed, } \\
\text { plankton, } \\
\text { minerals, } \\
\text { etc }\end{array}$ & $\begin{array}{c}2 / 3 / 4 \text { times } \\
\text { depends on } \\
\text { condition }\end{array}$ & $\begin{array}{l}\text { LB, white } \\
\text { spot }\end{array}$ & OTC & $1.2 \mathrm{~g} / \mathrm{ton}$ & & Unknown \\
\hline
\end{tabular}

\section{Stakeholder-based dialogue in Khulna}

In the stakeholder-based dialogue, the stakeholder groups discussed the issues within the group members and wrote their unanimous comments on the flip chart. Sufficient time was allocated for the group discussions. The group leaders presented group activity results (Table 3 ). 
Hatchery operators were blamed directly by the shrimp farmers but indirectly by the shrimp processors and other groups. Again shrimp/prawn farmers were blamed by the hatchery operators and others. Hatchery owners tried to defend them mentioning that they did not know about nitrofuran. But during questionnaire interview they told that they used such nitrofuran drugs 5-6 years back when these were not banned. During question-answer session they agreed on such abuse and requested for some safe drugs as effective replacement of nirrofuran. When asked about the unlabelled antibiotics found to be used in hatcheries, they said that unlabelled antibiotics were safe antibiotics but they kept those drugs confidential in order to protect the business monopoly. Hatchery operators deliberately argued for effective alternatives of nitrofuran in hatcheries. All these week arguments raised the index finger on to them that they might be one of the potential source to contaminating shrimp with nitrofuran in the hatcheries during PL production. Other probable sources of contamination in shrimp as came out during the discussion were huge nitrofuran drugs in poultry feed used as shrimp/prawn feed, the contaminants in natural water and soil, poultry litter, snail meat and agricultural chemicals.

\section{Stakeholder-based dialogue in Cox's Bazar}

Similar stakeholder based dialogue was conducted in Cox's Bazar. Here, hatchery team leader along with the team members showed strong difference as saying that if anybody blamed them for nitrofuran or any decision went against them, they would boycott the workshop. They tried to put forward many theoretical aspects of nitrofuran as displaying them that they knew about nitrofuran much better than others. At first, they told that they did not know about nitrofuran, neither its beneficial effects, nor its harmful characteristics. But soon they told that they used this drug 5-6 years back when it was not banned. One of the team members quoted that they had taken training on quality control of shrimp products along with nitrofuran type banned veterinary drug related issues, conducted by the FIQC, 4-5 years back. Such statement of one member was soon rejected by the team leader and other members as saying that they did not participate in any training of the FIQC on quality control or nitrofuran. The team themselves quarreled each other for some times on this issue. These proved some of them to be more biased on nitrofuran drugs. Irrelevant arguments and contradictory statements made by the hatchery technicians and hatchery consultants developed a strong web of doubt passing over the house that the hatchery technicians might use banned drugs in hatcheries. Hatchery technicians again pointed out that being an antibiotic, it could not be possible to detect nitrofuran derivatives in muscles as it would disappear within 2 weeks. So, what had been blaming to them on nitrofuran issue had no legal basis. But the fact is that nitrofuran derivatives readily disappear in the muscles within a few hours to few days due to tissue-bound formation of different metabolites, which are detectable by advanced liquid chromatography tandem mass spectrophotometry (LC-MS-MS) system (Hartig et al., 2005). Through these advanced technique nitrofuran metabolites could be detected in the muscles after long time of administration, even after 6-8 months (Hartig et al., 2005). However, at one stage of the dialogue, they became very angry upon as the whole house 
unanimously opined as being realized that the hatchery technicians were deliberately using many banned antibiotics in the hatcheries during PL production (Table 4).

Table 3. Findings of group discussion in stakeholder-based dialogue in Khulna

\begin{tabular}{|c|c|c|c|}
\hline Stakeholder & Form of chemicals in use & Probable source of nitrofuran & Measures required to stop use \\
\hline $\begin{array}{l}\text { Shrimp } \\
\text { Farmers }\end{array}$ & $\begin{array}{l}\text { - We do not use any antibiotics } \\
\text { either as feed or medicine } \\
\text { - only use Vit. C } \\
\text { - use CP Aqua Feed } \\
\text { - use probiotics for disease } \\
\text { control }\end{array}$ & $\begin{array}{l}\text { PL from hatchery } \\
\text { Natural feed } \\
\text { Various poultry feed } \\
\text { Pesticides from crop field }\end{array}$ & $\begin{array}{l}\text { Hatchery shouldn't use any } \\
\text { antibiotics; } \\
\text { Awareness raising campaign, } \\
\text { organizing meeting, workshop, } \\
\text { etc. are necessary. }\end{array}$ \\
\hline $\begin{array}{l}\text { Shrimp } \\
\text { Processors }\end{array}$ & $\begin{array}{l}\text { Use as antibiotic in hatchery; } \\
\text { Use growth promoter in } \\
\text { rearing and culture. }\end{array}$ & $\begin{array}{l}\text { Hatchery operators are using; } \\
\text { Shrimp farmers are using these } \\
\text { drugs; PL of other countries } \\
\text { may carry drugs. }\end{array}$ & $\begin{array}{l}\text { Citable penalty for abusers; } \\
\text { Immediate establishment of } \\
\text { detection lab; Strong regulations } \\
\text { and their application required. }\end{array}$ \\
\hline $\begin{array}{l}\text { Hatchery } \\
\text { Operators }\end{array}$ & $\begin{array}{l}\text { We do not use nitrofuran and } \\
\text { chloramphenicol; } \\
\text { - use OTC only }\end{array}$ & $\begin{array}{l}\text { Farmer use as poultry and } \\
\text { shrimp feed; } \\
\text { - as poultry litter } \\
\text { Indian PL }\end{array}$ & $\begin{array}{l}\text { Alternative of nitrofuran to be } \\
\text { introduced immediately for the } \\
\text { hatchery; } \\
\text { Central detecting lab to be set }\end{array}$ \\
\hline $\begin{array}{l}\text { Depot } \\
\text { Holder: }\end{array}$ & $\begin{array}{l}\text { We do not use any antibiotics } \\
\text { or chemical }\end{array}$ & $\begin{array}{l}\text { Poultry and shrimp feed } \\
\text { Farmer use as growth promoter }\end{array}$ & $\begin{array}{l}\text { Screening of feed } \\
\text { Stop importing poultry feed } \\
\text { Awareness development }\end{array}$ \\
\hline NGOs & Both as medicine \& feed & $\begin{array}{l}\text { Hatchery PL } \\
\text { Non-deliberate use by farmers }\end{array}$ & $\begin{array}{l}\text { Strict monitoring in hatcheries, } \\
\text { Screening feed \& feed } \\
\text { ingredients }\end{array}$ \\
\hline $\begin{array}{l}\text { Feed } \\
\text { Processors }\end{array}$ & $\begin{array}{l}\text { We do not use any antibiotics } \\
\text { or chemicals in CP Feed; } \\
\text { CP Feed is free from any } \\
\text { antibiotics; } \\
\text { Certified by BCSIR }\end{array}$ & Natural contamination; & $\begin{array}{l}\text { Antibiotic detecting lab to be } \\
\text { established in the country; } \\
\text { Nitrofuran-free high quality } \\
\text { feed for prawn/ shrimp should } \\
\text { used. }\end{array}$ \\
\hline PL Traders & $\begin{array}{l}\text { We do not use any antibiotics } \\
\text { or chemicals }\end{array}$ & $\begin{array}{l}\text { Hatcheries PL are week and } \\
\text { mortality is high; So chemicals } \\
\text { and illegal antibiotics are used } \\
\text { to increase survival rate. }\end{array}$ & $\begin{array}{l}\text { Strict monitoring in hatcheries; } \\
\text { Strict regulation on banned } \\
\text { chemicals }\end{array}$ \\
\hline
\end{tabular}

Shrimp farmers and mother shrimp collectors directly blamed the hatcheries for using such illegal drugs. Other stakeholders like research institute, feed processors, depot holders, and shrimp processors indirectly blamed the hatcheries for bringing nitrofuran contamination in shrimp. Depot holders and others mentioned that feed would be one of the major source of contamination. NGOs told that although now unknown to them but definitely some of the present stakeholders might have been using such illegal antibiotics in hatcheries or farms. For the sake of the nation, they added, "we should have moral courage to confess the blame for not to use these banned items further." 
Table 4. Findings of group discussion in stakeholder-based dialogue in Cox's Bazar

\begin{tabular}{|c|c|c|c|}
\hline $\begin{array}{c}\text { Different } \\
\text { stakeholder }\end{array}$ & $\begin{array}{l}\text { Form of chemicals in } \\
\text { use }\end{array}$ & Probable source of nitrofuran & Measures required to stop use \\
\hline $\begin{array}{l}\text { Shrimp } \\
\text { Farmers }\end{array}$ & $\begin{array}{l}\text { Unknown to us } \\
\text { May be as antibiotic }\end{array}$ & $\begin{array}{l}\text { We do not use in pond or ghers; } \\
\text { Shrimp hatcheries are using } \\
\text { nitrofuran during PL production }\end{array}$ & $\begin{array}{l}\text { Government should take legal } \\
\text { action against use of nitrofuran }\end{array}$ \\
\hline $\begin{array}{l}\text { Hatchery } \\
\text { Operators }\end{array}$ & $\begin{array}{l}\text { We do not know about } \\
\text { nitrofuran. } \\
\text { We do not know the } \\
\text { harmful/beneficial } \\
\text { effect of it }\end{array}$ & $\begin{array}{l}\text { No body is using nitrofuran in } \\
\text { Bangladesh. First, detect it by } \\
\text { appropriate instrument, then } \\
\text { blame any body }\end{array}$ & $\begin{array}{l}\text { Concerned institute should take } \\
\text { the responsibility. Government } \\
\text { should collect different field } \\
\text { information. } \\
\text { Research required for alternative } \\
\text { safe antibiotics for hatchery use }\end{array}$ \\
\hline $\begin{array}{l}\text { Depot } \\
\text { Holder }\end{array}$ & $\begin{array}{l}\text { May be as antibiotic. } \\
\text { For good health and } \\
\text { rapid growth }\end{array}$ & $\begin{array}{l}\text { Many stakeholders like hatcheries, } \\
\text { farmers, feed processors might be } \\
\text { using but there is no proof }\end{array}$ & $\begin{array}{l}\text { All of us have to aware about the } \\
\text { use of nitrofuran }\end{array}$ \\
\hline NGOs & $\begin{array}{l}\text { As antibiotic. } \\
\text { As growth enhancer. }\end{array}$ & $\begin{array}{l}\text { Exactly not known, but definitely } \\
\text { several stakeholders who are also } \\
\text { present in this workshop are using }\end{array}$ & $\begin{array}{l}\text { Create awareness. } \\
\text { Identify source and take strong } \\
\text { punitive action }\end{array}$ \\
\hline Fry Traders & As chemical fertilizer & Unknown to us & $\begin{array}{l}\text { Problems, whatever may be } \\
\text { strong, should be addressed } \\
\text { collectively; It should be addressed } \\
\text { nationally with strong regulations }\end{array}$ \\
\hline $\begin{array}{l}\text { Feed } \\
\text { Processors }\end{array}$ & $\begin{array}{l}\text { As antibiotics to cure } \\
\text { disease }\end{array}$ & $\begin{array}{l}\text { In shrimp/prawn } \\
\text { hatcheries. } \\
\text { In shrimp farms/ponds for } \\
\text { disease control }\end{array}$ & $\begin{array}{l}\text { Improved nutritional feed is } \\
\text { required for healthy growth }\end{array}$ \\
\hline $\begin{array}{l}\text { Shrimp } \\
\text { Processors }\end{array}$ & $\begin{array}{l}\text { As antibio. } \\
\text { As Antibiotic. } \\
\text { As growth promoter }\end{array}$ & $\begin{array}{l}\text { Somebody must be using, } \\
\text { otherwise it would not have been } \\
\text { detected repeatedly and } \\
\text { consignment rejected regularly }\end{array}$ & $\begin{array}{l}\text { Awareness creation \& campaign; } \\
\text { LC-MS-MS machine should be } \\
\text { installed, DoF training program } \\
\text { for FIQC people; Advanced } \\
\text { research required on banned drug } \\
\text { abuse }\end{array}$ \\
\hline
\end{tabular}

\section{CONCLUSION}

Both survey and stakeholder-based dialogues revealed that most of the stakeholders did not know about nitrofuran or other illegal drugs before. Many stakeholders blamed that nitrofuran type illegal drugs have still been used in the shrimp hatcheries and ponds for disease control and rapid growth. But the hatchery owners did not confess the blame. A strong doubt was raised against shrimp/prawn feed producers/suppliers, local or imported, which were supposed to be contaminated with illegal growth enhancing drugs. Feed processors/distributors also did not confess such blames. In such ambiguity, direct detection of nitrofuran metabolites in representative samples of shrimp/prawn hatchery PL, feed, products, water and soil samples through advanced technologies are required. 


\section{ACKNOWLEDGEMENT}

The study was funded by the DFID through Bangladesh Fisheries Research Forum (BFRF).

\section{REFERENCES}

DoF. 2006. Status of frozen food export. Department of Fisheries. Ministry of Fisheries and Livestock. Bangladesh.

Finzi, J. K., L. J. Donato, M. Sucupira and D. G. Nucci. 2005. Determination of nitrofuran metabolites in poultry muscle and eggs by liquid chromatography-tandem mass spectrometry. J. Chromatography B. 824: 30-35.

Hartig, L. and C. K. Von. 2005. Detecting nitrofuran metabolites in animal products using LC/MS/MS. Food Additives and Contaminants. 17(3): 205-211. 